Brazilian Journal

of Chemical

Engineering

ISSN 0104-6632

Printed in Brazil

www.abeq.org.br/bjche

Vol. 36, No. 02, pp. 627 - 637, April - June, 2019

dx.doi.org/10.1590/0104-6632.20190362s20180360

\title{
OPTIMIZATION OF BIOFLOCCULANT PRODUCTION BY Bacillus spp. FROM SUGARCANE CROP SOIL OR FROM SLUDGE OF THE AGROINDUSTRIAL EFFLUENT
}

\author{
Jéssica G. Gouveia ${ }^{1}$, Amanda L. dos S. Silva ${ }^{1}$, Elane C. L. dos Santos ${ }^{1}$, \\ Everton S. Martins ${ }^{1}$ and Ana M. Q. López ${ }^{1 *}$ \\ ${ }^{1}$ Universidade Federal de Alagoas, Instituto de Química e Biotecnologia, Laboratório de Bioquímica do Parasitismo e Microbiologia
Ambiental, Maceió, AL, Brasil. ORCID: 0000-0003-3601-014X; ORCID: 0000-0002-5949-2199; ORCID: 0000-0002-0941-7465;
} ORCID: 0000-0001-8867-5165; E-mail: amql@qui.ufal.br - ORCID: 0000-0002-8418-3507

(Submitted: August 1, 2018 ; Revised: November 8, 2018 ; Accepted: November 19, 2018)

\begin{abstract}
Biological flocculants are advantageous due to their biodegradability and safety to living beings. In this work, four bacterial strains, isolated from sugarcane cropped soil (Bacillus megaterium LBPMA-APFSG3Isox and B. toyonensis LBPMA-ACOPR1.Isox) and sludge of an agroindustrial effluent (B. pumilus LBPMA-BLD07 and B. thuringiensis LBPMA-EFIII), were studied. It was found that all of them secreted bioflocculants, at $37 \pm 1$ ${ }^{\circ} \mathrm{C}$, with no $\mathrm{pH}$ changes over time and the flocculant activity increased during the time course of incubation. These results stimulated the optimization of the culture conditions to improve flocculation rates, such as the $\mathrm{pH}$, nitrogen sources and carbon. For B. toyonensis LBPMA-ACOPR1.Isox and B. thuringiensis LBPMA-EFIII, the best $\mathrm{pH}$ for the bioflocculant production was 5.0. Sucrose and maltose were the best sources of carbon, while urea was the preferred source of nitrogen for two of the tested isolates (B. pumilus LBPMA-BLD07 and B. toyonensis LBPMAACOPR1.Isox), followed by $\left(\mathrm{NH}_{4}\right) 2 \mathrm{SO}_{4}$ (B. megaterium LBPMA-APFSG3Isox) and peptone (B. thuringiensis LBPMA-EFIII). The FTIR-ATR spectra of each extracted material responsible for the flocculant activities of the strains displayed carboxyl, hydroxyl and methoxy functional groups characteristic of polysaccharides.

Keywords: Bioflocculation; Bacillus; Polysaccharides secretion.
\end{abstract}

\section{INTRODUCTION}

Biological diversity is an important source for the development of sustainable tools for ecosystem management and opportunities of substances prospection, especially concerning microorganisms, since this life-group is still unknown compared to others such as animals and plants (Pylro et al., 2014), and they survive and proliferate in distinct environments, from natural to human managed. Hence, their biochemical adaptation makes microbial cells promising tools for biotechnological and ecoefficient utilization. The greatest challenge to rational use of such biodiversity is definitely transforming a high natural genetic heritage into biotechnological richness (Pylro et al., 2014).

Biological processes have conquered a remarkable place in global technological development, exhibiting economical and operational characteristics that confer a benefit regarding classical chemical methods (Barros et al., 2013). The Bacillus genus is one of the principal contributors to this issue. It can produce, for example, enzymes utilized to manufacture detergents and paper pulp, besides biosurfactant, polyhydroxyalkanoates (bioplastics) and bioflocculants. Their species are easily cultivated under different laboratorial conditions and can inhibit the growth of other microorganisms. These characteristics

*Corresponding author: Ana M. Q. López - E-mail: amql@qui.ufal.br 
stimulate screening for strains expressing the synthesis of bioproducts suitable for different environments, especially for certain industrial processes (Martins and Hatti-Kaul, 2002). In this context, researchers have sequenced the complete genomes of bioflocculantproducing strains (Liu et al., 2017).

On another hand, the increase in industrial activities generates a large amount of effluent that can become a serious environmental problem, mainly when untreated wastewater is discharged into water bodies. In Brazil, there is a governamental environmental Council (CONAMA- "Conselho Nacional do Meio Ambiente") that established limits for some parameters for such destination of residues, mainly through legal resolution 430/2011 (CONAMA, 2011). This led to an increase in chemical flocculant utilization for wastewater treatment.

The purpose of the flocculation process is to form aggregates from finely dispersed particles in the presence of natural or synthetic polymeric substances called flocculants. The chemical flocculants are efficient and inexpensive, but have carcinogenic properties (Moussas and Zouboulis, 2009). On the other hand, bioflocculants are secondary metabolites produced during the growth of microorganisms (such as bacteria, fungi and algae), composed predominantly of polysaccharides, proteins, nucleic acids and lipids (Okaiyeto et al., 2015). Among these macromolecules, polysaccharide-based bioflocculant deserve attention due to their biodegradability, high flocculation taxes for metal removal and for use in wastewater treatment (Li et al., 2009; Liu et al., 2010). Few Brazilian studies have been published regarding this significant matter, and the purpose of this work was to screen Bacillus strains previously selected for being tolerant to the herbicides isoxaflutole, sulfentrazone and diuron, or producers of polyhydroxyalkanoates/biosurfactants, their capacity to also synthetize bioflocculant.

\section{MATERIALS AND METHODS}

\section{Source of bacteria and inoculum preparation}

Fourbacterial strains maintained in the Biochemistry Laboratory of Parasitism and Environmental Microbial (Chemistry and Biotechnology Institute of University Federal of Alagoas, Brazil) were used. Two microorganisms (Bacillus megaterium LBPMAAPFSG3Isox and B. toyonensis LBPMA-ACOPR1. Isox) were obtained for the Atlantic Forest whose soil possesses a history of herbicide application, while $B$. pumilus LBPMA-BLD07 and B. thuringiensis LBPMA-EFIII were isolated from sludge of a Wastewater Treatment Effluent Station (Coruripe-AL, Brazil). The inoculum was prepared by reactivation of microbial strains on nutrient agar, during $24 \mathrm{~h}$ (at $32 \pm 1{ }^{\circ} \mathrm{C}$, dark). Then, $9 \mathrm{~mL}$ of sterile water were used to suspend each strain from the Petri dishes, and this suspension was submitted to a serial dilution to $10^{8}$ cells. $\mathrm{mL}^{-1}$, using liquid media for bioflocculant production, prepared as described below.

\section{Bioflocculant production}

Triplicates of each culture were prepared using aliquots of the particular inoculum suspension in $75 \mathrm{~mL}$ of the specific medium in Erlenmeyer flasks $(125 \mathrm{~mL})$ to reach $10^{8}$ cells. $\mathrm{mL}^{-1}$. The mixture was incubated for $120 \mathrm{~h}$ at $37 \pm 1^{\circ} \mathrm{C}$ in the dark and under orbital shaking at $160 \mathrm{rpm}$ (the control was maintained without addition of bacteria). At intervals of $24 \mathrm{~h}$, dried biomass, bioflocculant activity and $\mathrm{pH}$ were evaluated in samples of the different cultures. The medium for bioflocculant production was composed ( $\left.\mathrm{g} \mathrm{L}^{-1}\right)$ of: 20 glucose, 0.5 urea, 0.5 yeast extract, $0.3\left(\mathrm{NH}_{4}\right)_{2} \mathrm{SO}_{4}, 2$ $\mathrm{KH}_{2} \mathrm{PO}_{4}, 5 \mathrm{~K}_{2} \mathrm{HPO}_{4}, 0.1 \mathrm{NaCl}$ and $0.2 \mathrm{MgSO}_{4} \cdot 7 \mathrm{H}_{2} \mathrm{O}$. Initial $\mathrm{pH}$ was adjusted to 7.0 (Zhang et al., 2007).

The whole experiment was divided into two stages. The first one was the analysis of the bacteria behavior during the time course $(120 \mathrm{~h})$, and the second was the selection of the best $\mathrm{pH}$, carbon and nitrogen sources for bioflocculant production among the tested ones, after $24 \mathrm{~h}$ of incubation as above mentioned.

After centrifugation (5000 rpm, $20 \mathrm{~min}, 4{ }^{\circ} \mathrm{C}$ ), the $\mathrm{pH}$ values of the supernatants free of cells were obtained with a $\mathrm{pH}$ meter. Precipitated cells were ressuspended in $1 \mathrm{~mL}$ of sterile distilled water and transferred to $1.5 \mathrm{~mL}$ Eppendorf microtubes, which were submitted to drying in the oven $\left(40{ }^{\circ} \mathrm{C}\right.$ during $24 \mathrm{~h}$ ) until constant mass. Aliquots of $2 \mathrm{~mL}$ of the supernatant medium obtained after new centrifugation (5000 rpm, $30 \mathrm{~min}$ ) were used as the test bioflocculant to determine the flocculating activity as described by Kurane et al. (1994). Briefly, $100 \mathrm{~mL}$ of kaolin suspension was added to $3 \mathrm{~mL}$ of $1 \% \mathrm{w} / \mathrm{v} \mathrm{CaCl}_{2}$ and supernatant. The mixture was agitated vigorously for $60 \mathrm{~s}$ and then poured into a glass volumetric cylinder $(100 \mathrm{~mL})$ and allowed to sediment for $5 \mathrm{~min}$ at room temperature. The optical density (OD) of the clarifying supernatant was measured at $550 \mathrm{~nm}$ with a UV spectrophotometer (Thermo Spectronic, USA) and the flocculating activity determined as follows: Flocculating Activity $(\%)=[(\mathrm{B}-\mathrm{A}) / \mathrm{A}] \mathrm{x} 100$, where $\mathrm{A}$ and $\mathrm{B}$ are optical densities of control and samples, respectively, measured at $550 \mathrm{~nm}$ (Pathak et al., 2018).

\section{Effects of initial pH, carbon and nitrogen sources}

To determine the best sources of carbon and nitrogen of medium composition for bioflocculant production, each microorganism was inoculated in Falcon tubes $(50 \mathrm{~mL})$ containing $40 \mathrm{~mL}$ of specific medium for bioflocculant production.

The initial $\mathrm{pH}$ value was adjusted to 3.0, 5.0, 7.0 or 9.0 using $\mathrm{NaOH} 1.0 \mathrm{M}$ or $\mathrm{HCl} 1.0 \mathrm{M}$ in different 
culture media, to identify the best condition. Flocculant activity and dried biomass were analyzed after $24 \mathrm{~h}$ of incubation.

The carbon sources $\left(20 \mathrm{~g} \mathrm{~L}^{-1}\right)$ utilized were: sucrose, maltose and glucose. Urea, peptone, ammonium sulfate and a mixed source of nitrogen (yeast extract, ammonium sulfate and urea) were used as nitrogen sources $\left(1.3\right.$ g. $\left.\mathrm{L}^{-1}\right)$.

\section{Extraction and purification of the bioflocculant}

Extraction and purification of bioflocculant produced by the studied bacterial strains were realized as described by Wong et al. (2012) with some modifications. After the selection of the best initial $\mathrm{pH}$, carbon and nitrogen sources, and conditions for bioflocculant production, the culture broth incubated for $72 \mathrm{~h}$ was centrifuged $\left(4,000 \mathrm{~g}, 15 \mathrm{~min}, 4^{\circ} \mathrm{C}\right)$ and two volumes of ethanol were added to the supernatant. The mixtures were stirred and left to stand for $24 \mathrm{~h}$ at $4{ }^{\circ} \mathrm{C}$. The pellet (bioflocculant) was recovered by centrifugation and dissolved in $25 \mathrm{~mL}$ of distilled water with a mixture of chloroform and 1-butanol $(5: 2 \mathrm{v} / \mathrm{v})$. After shaking, the mixture was left standing at room temperature for $12 \mathrm{~h}$ in a separation-hopper (room temperature). The superior phase was recovered, centrifuged, redissolved in $50 \mathrm{~mL}$ distilled water and left to stand at $40{ }^{\circ} \mathrm{C}$. The result was a dry powdered bioflocculant which was characterized as described below.

\section{Bioflocculant characterization}

To determine the functional portions of bioflocculant, the infrared spectra of the dried bioflocculants were recorded in the frequency range of $4000-400 \mathrm{~cm}^{-1}$ by a Fourier Transform Infrared-Raman Spectrophotometer (Shimadzu, model IRPrestige-21).

\section{Statistical analysis}

All the assays were repeated three times, with analysis in triplicate. The results were expressed as mean \pm standard deviation, and the analysis of variance (ANOVA) was carried out to verify if there were significant differences $(\rho<0.05)$. Also, the Tukey's test was utilized to verify the significant differences ( $\rho$ $<0.05)$. among the means.

\section{RESULTS AND DISCUSSION}

\section{Evaluation of bioflocculant activity}

Under the assay conditions established, the studied Bacillus strains were able to increasingly synthetize bioflocculant in parallel with cell growth. The maximum flocculant activity (MFA) was $57 \%$ for $B$. pumilus LBPMA-BLD07, after $72 \mathrm{~h}$ of incubation, while $B$. thuringiensis LBPMA-EFIII, $B$. toyonensis LBPMA-ACOPR1.Isox and B. megaterium LBPMA-
APFSG3Isox presented respectively $33 \%, 21 \%$ and $34 \%$ of this activity after $24 \mathrm{~h}$. From this time point, the flocculant activity gradually decreased, proportional to the decrease of the dried biomass in the studied medium (Figure 1). These results agree with observations of Xia et al. (2008), who found maximum flocculating activity (MFA) was reached in the beginning of the stationary phase. This can be explained by the lower number of cells (at that moment, there is depletion of nutrients), so the secretion of products like bioflocculants is also reduces (Nwodo and Okoh, 2013).

Yang et al. (2012) also reported that Klebsiella sp $\mathrm{N}-10$ isolated from activated sludge achieved its MFA $(86.5 \%)$ at $60 \mathrm{~h}$ of cultivation. Likewise, Okaiyeto et al. (2016) registered MFA of $85.8 \%$ after $72 \mathrm{~h}$ of cultivation for Bacillus sp. AEMREG7. Others studies relate that $B$. mojavensis, $B$. licheniformis $\mathrm{X}-14$ and Klebsiella sp. TG-1 achieved their MFA after 24, 20 and $28 \mathrm{~h} \mathrm{(Li,} \mathrm{2009;} \mathrm{Sekelwa} \mathrm{et} \mathrm{al.,} \mathrm{2013).} \mathrm{Although}$ fungi and bacterial growth present different tendencies, Aljuboori et al. (2013) also showed that Aspergillus flavus had MFA $(87.2 \%)$ in a medium containing (g.L$\left.{ }^{1}\right)$ sucrose, 30 ; peptone, $3.0 ; \mathrm{MgSO}_{4} \cdot 7 \mathrm{H}_{2} \mathrm{O}, 0.5 ; \mathrm{KCl}$, $0.5 ; \mathrm{FeSO}_{4}, 0.01 ; \mathrm{K}_{2} \mathrm{HPO}_{4}, 1.0$, at initial $\mathrm{pH} 6.0$, after $60 \mathrm{~h}$ of incubation.

In the present study, the temperature of $37{ }^{\circ} \mathrm{C}$ favored the growth as well as the bioflocculant production by the studied bacterial strains. According to Salehizadeh and Shojaosadati (2001) and Zhang et al. (2007), the enzymes which are responsible for bioflocculant production are activated in a temperature range between $25^{\circ} \mathrm{C}$ and $37^{\circ} \mathrm{C}$.

Regarding the $\mathrm{pH}$, since no significative alterations from the initial value (7.0) happened, it is probable that the composition of the medium has a good buffer composition and it is efficient for the bioflocculant synthesis by the studied strains. Prasertsan et al. (2006) found that Enterobacter cloacae WD7 bioflocculant activity was optimal at $\mathrm{pH}$ 6.0. On the other hand, $\mathrm{Li}$ et al. (2010) verified that Agrobacterium sp. M-503 produced bioflocculant with high activity at neutral to alkaline $\mathrm{pH}$ (7-12). Wang et al. (2011) observed that the MAF of the CBF-F26 bioflocculant (mixed culture of Rhizobium radiobacter F2 and B. sphaericus F6) occurred in neutral and weak alkaline conditions, while Xiong et al. (2010) detected MFA of B. licheniformis CGMCC 2876 at $\mathrm{pH} 7.5$.

With respect to non-bacterial organisms, Deng et al. (2005) reported that the bioflocculant was secreted by the fungus $A$. parasiticus in a $\mathrm{pH}$ range of 5.0-6.0, and the increase in $\mathrm{pH}$ decreased the biomass and bioflocculant activity production, while the lower $\mathrm{pH}$ favored the synthesis, secretion and accumulation of the bioflocculant in the medium. It was observed that the flocculation efficiency of the biopolymer produced by dinoflagellate Gyrodinium impudicum KG03 was 


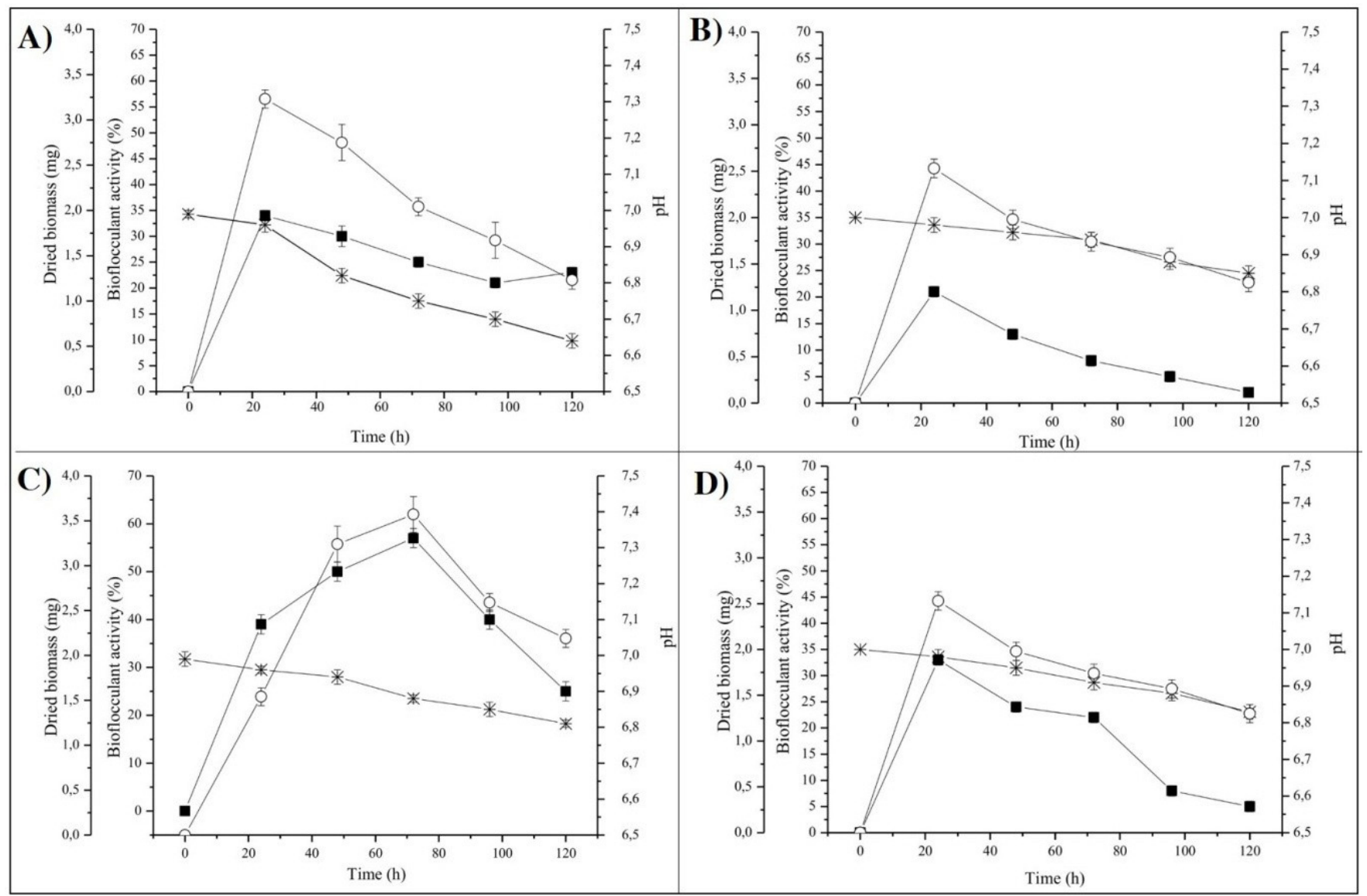

Figure 1. Percentage of bioflocculant activity using kaolin suspension ( $\mathbf{})$, dried biomass $(\mathrm{O})$ and $\mathrm{pH}(*)$ of the cultures (glucose as carbon source) of Bacillus megaterium LBPMA-APFSG3Isox (A), B. toyonensis LBPMAACOPR1.Isox (B), B. pumilus LBPMA-BLD07 (C) and B. thuringiensis LBPMA-EFIII (D), during $120 \mathrm{~h}$ of incubation (at $37^{\circ} \mathrm{C}$, dark, $160 \mathrm{rpm}$ of orbital shaking).

optimal within a $\mathrm{pH}$ range of 3.0-6.0 (MFA at $\mathrm{pH} 4.0)$ (Yim et al., 2007).

Several other factors, besides the $\mathrm{pH}$ (Salehizadeh and Yan, 2014), temperature (Nakata and Kurane, 1999), cell concentration and macro and micronutrients, can affect MAF in a given environment. The agitation speed, for example, determines the concentration of dissolved oxygen available, which interferes with the absorption of nutrients and enzymatic reactions of bioflocculant production. Once the nutrients deplete in the culture, the level of oxygen available to the microorganisms becomes reduced, as well as the products of toxic residues of the metabolic activity, such as the presence of some deflocculating enzyme among them, which increases drastically the number of cells still viable and the accumulation of secreted flocculants (Zheng et al., 2008). According to Li et al. (2009), the optimum shaking speed for bioflocculant production by the strain of B. licheniformis X14 was 140-160 rpm.

\section{Optimization of culture medium for bioflocculant production}

Several carbon sources can stimulate specific microorganisms to produce bioflocculants. In the present study, different carbon sources (sucrose, glucose and maltose), at four $\mathrm{pH}$ values $(3.0 ; 5.0 ; 7.0$ and 9.0) for production of bioflocculants by different strains of Bacillus spp. were evaluated. Similarly, Guo et al. (2018) investigated bioflocculant production of Pseudomonas boreopolis G22 under different $\mathrm{pHs}$ (5 - 10). In the present study, sucrose was the most favorable carbon source for bioflocculant production by $B$. megaterium LBPMA-APFSG3Isox, and $B$. toyonensis LBPMA-ACOPR1.Isox, respectively, with $41 \%$ and $39 \%$ bioflocculating activity after $24 \mathrm{~h}$. For $B$. pumilus LBPMA-BLD07 and B. thuringiensis LBPMA-EFIII, maltose was the best source of carbon to stimulate this bioflocculant activity (13\% and $25 \%$, respectively) (Figures 2 and 3).

Similar findings were reported by Makapela et al. (2016) with a strain of B. pumilus from Thyume River in Alice, Eastern Cape (South Africa). For this strain, maltose and sucrose were the favorable carbon sources for the production of bioflocculants (respectively $71.7 \%$ and $69.8 \%$ of activities), after 120 $\mathrm{h}$ of incubation in a production medium composed of (g.L $\mathrm{L}^{-1}$ ): maltose, $20 ; \mathrm{K}_{2} \mathrm{HPO}_{4}, 5 ; \mathrm{KH}_{2} \mathrm{PO}_{4}, 2$, urea 0.5 ; yeast extract, $0.5 ;\left(\mathrm{NH}_{4}\right)_{2} \mathrm{SO}_{4}, 0.2$ and $\mathrm{MgSO}_{4} \cdot 7 \mathrm{H}_{2} \mathrm{O}$, 


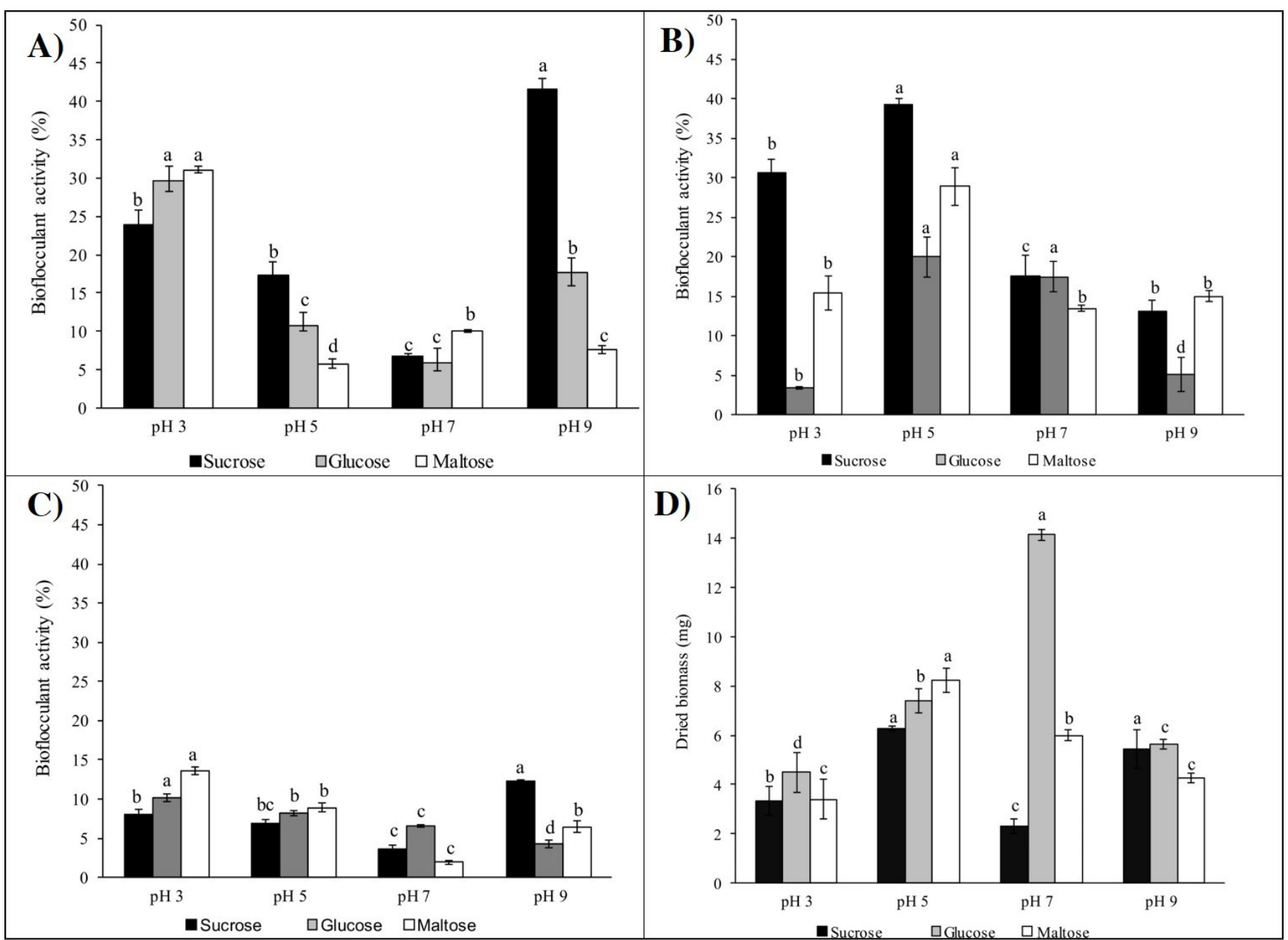

Figure 2. Effect of carbon sources and $\mathrm{pH}$ on the bioflocculant production by Bacillus megaterium LBPMAAPFSG3Isox (A), B. toyonensis LBPMA-ACOPR1.Isox (B), B. pumilus LBPMA-BLD07 (C) and B. thuringiensis LBPMA-EFIII (D), after $24 \mathrm{~h}$ of incubation (at $37^{\circ} \mathrm{C}$, dark, $160 \mathrm{rpm}$ of orbital shaking). For each strain, bars of the same color followed by different letters indicate subgroups with statistically significant differences, according to Tukey test $(\rho<0.05)$.

0.2. Similarly, Wan et al. (2013) reported that maltose was the preferred carbon source for the production of bioflocculants by Solibacillus silvestris, isolated from activated sludge, showing $88.7 \%$ flocculant activity after $72 \mathrm{~h}$ of incubation in a medium containing (g.L${ }^{1}$ ): yeast extract, $10 ; \mathrm{KH}_{2} \mathrm{PO}_{4}, 1$ and $\mathrm{MgSO}_{4} \cdot 7 \mathrm{H}_{2} \mathrm{O}, 1 \mathrm{~g}$; at $\mathrm{pH}$ 7.0. In addition, Luo et al. (2016), using a strain of B. megaterium (isolated from biofloc in pond water) and sucrose as carbon source, obtained bioflocculant activity higher than $80 \%$ after $72 \mathrm{~h}$ of incubation.

These findings support the affirmation that preferences forcarbon sources to produce bioflocculants vary among microorganisms (Salehizadeh and Yan, 2014), but also that the ability of most of them to use sucrose as a carbon source for such synthesis led to the option of using molasses for the production on an industrial scale (Okaiyeto et al., 2016).

Regarding the medium- $\mathrm{pH}$, the best bioflocculant production was obtained at $\mathrm{pH} 5.0$ for $B$. toyonensis
LBPMA-ACOPR1.Isox and B. thuringiensis LBPMAEFIII, and at $\mathrm{pH} 3.0$ for $B$. pumilus LBPMA-BLD07 and $\mathrm{pH} 9.0$ for $B$. megaterium LBPMA-APFSG3Isox. Choi et al. (1998) and Zheng et al. (2008), reported that the activities of the polysaccharide flocculants of Anabaena sp. PC-1 and Bacillus sp. F19 decrease as the $\mathrm{pH}$ increases, probable because of the interference of the hydroxyl ion $\left(\mathrm{OH}^{-}\right)$during the formation of the complex bioflocculant-clay, mediated by the metallic ions, finally leading to its suspension.

On the other hand, Zheng et al. (2008) found a maximum flocculation activity for $B$. megaterium strain from soil when it was grown in medium with $\mathrm{pH}$ ranging from acid to very alkaline, at initial $\mathrm{pH} 9.0$. He et al. (2010), in turn, studying the activity of a bioflocculant produced by Halomonas sp. V3a, found that it was higher than $80 \%$ in the $\mathrm{pH}$ range of $3-11$, with the highest flocculation (97\%) at $\mathrm{pH} 7.0$. The optimum initial $\mathrm{pH}$ of the growth medium aiming at the best bioflocculant 


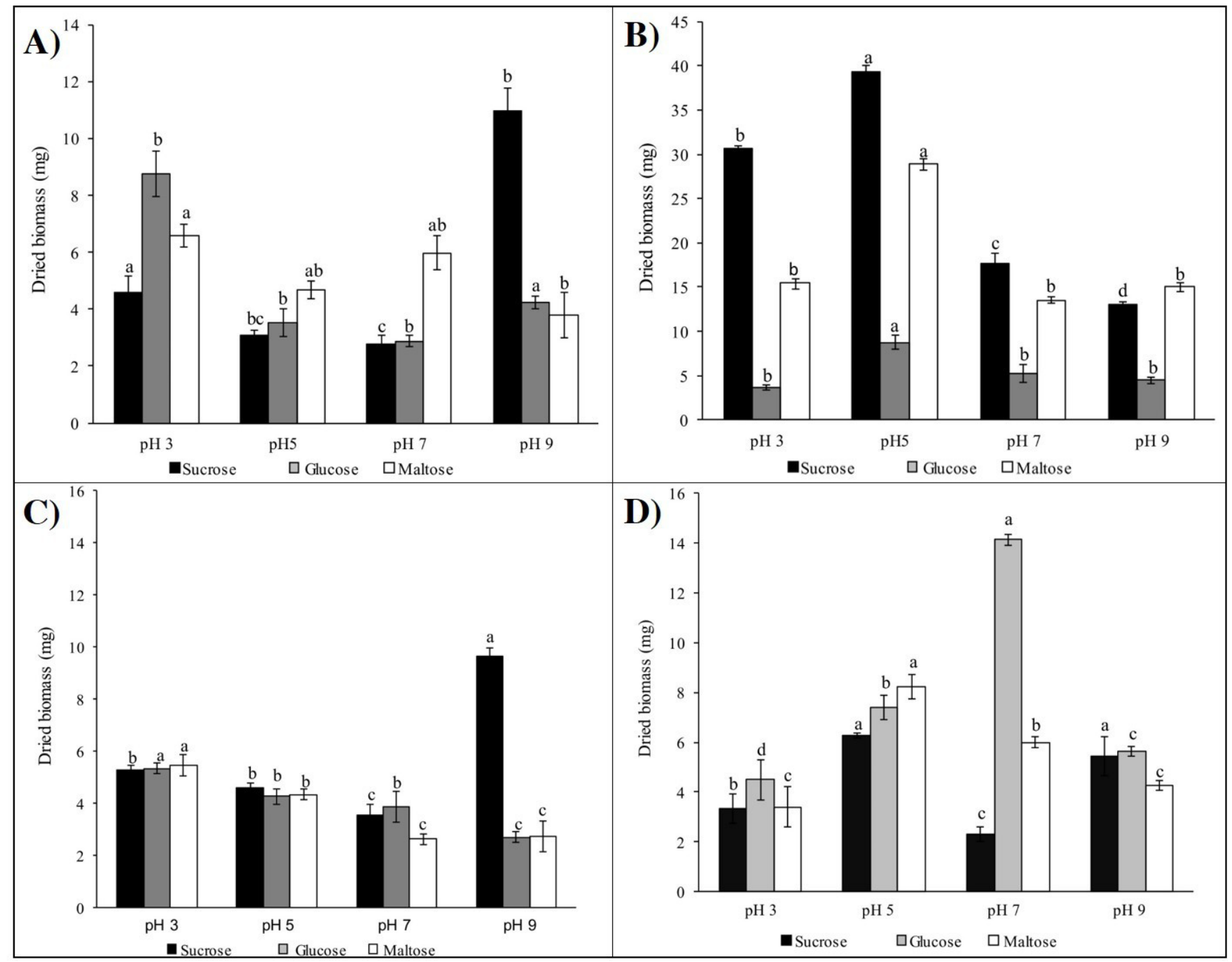

Figure 3. Effect of carbon sources and $\mathrm{pH}$ on the dried biomass of Bacillus megaterium LBPMA-APFSG3Isox (A), B. toyonensis LBPMA-ACOPR1.Isox (B), B. pumilus LBPMA-BLD07 (C) and B. thuringiensis LBPMA-EFIII (D), after $24 \mathrm{~h}$ of incubation (at $37^{\circ} \mathrm{C}$, dark, $160 \mathrm{rpm}$ of orbital shaking). For each strain, bars of the same color followed by different letters indicate subgroups with statistically significant differences, according to Tukey test $(\rho<0.05)$.

activities of Bacillus xn12 and Streptomyces xn17 (97\% for both) was observed at $\mathrm{pH} 5.0$ (Dongchen et al., 2013). On the other hand, Okaiyeto et al. (2015), using a strain of B. toyonensis from sediment of Algoa Bay of the Eastern Cape Province (South Africa), found a best bioflocculant production under acidic conditions, especially at $\mathrm{pH}$ 5.0.

To evaluate the effect of nitrogen sources, the best combination carbon source and $\mathrm{pH}$ value of the initial culture medium for bioflocculant production was selected, using the ratio of flocculation activity to driedcell biomass $(\mathrm{A} / \mathrm{m})$. Therefore, these best combinations, as described in Table 1 for $B$. megaterium LBPMAAPFSG3Isox, $B$. thurigiensis LBPMA-EFIII and $B$. toyonensis LBPMA-ACOPR1.Isox were sucrose (respectively ratios of 5.66 in $\mathrm{pH} 3.0$ and 3.73 and 7.92 in $\mathrm{pH}$ 5.0) and maltose for B. pumilus LBPMA-BLD07 (highest ratio of $2.49 \mathrm{in} \mathrm{pH} 3.0$ ).
As can be seen in Figure 4, among the nitrogen sources analyzed, $\left(\mathrm{NH}_{4}\right)_{2} \mathrm{SO}_{4}$ provided the best flocculating activity $(36 \%)$ for $B$. megaterium LBPMA-APFSG3Isox, whilst urea made the same for B. pumilus LBPMA-BLD07 (36\%) and B. toyonensis LBPMA-ACOPR1.Isox (22\%), and peptone for $B$. thuringiensis LBPMA-EFIII (26\%) (Figure 4).

According to Okaiyeto et al. (2016), a strain of Bacillus from sediment of Algoa Bay of the Eastern Cape Province (South Africa), incubated by $72 \mathrm{~h}$ in medium with $\left(\mathrm{NH}_{4}\right)_{2} \mathrm{SO}_{4}$ as source of nitrogen showed a bioflocculant activity of $79.89 \%$. Sheng et al. (2006), studying the production of bioflocculant by a strain of Klebsiella sp., also found that ammonium sulphate was the best nitrogen source to stimulate its synthesis. On the other hand, Li et al. (2013) found that peptone was the best source for flocculant production by Paenibacillus elgii B69, and the same was seen for 
Table 1. The ratio of bioflocculant activity/dried cell growth of four Bacillus strains tested after $24 \mathrm{~h}$ of incubation (at $37^{\circ} \mathrm{C}$, dark, $160 \mathrm{rpm}$ orbital shaking).

\begin{tabular}{lcccc}
\hline \multirow{2}{*}{ Strains } & \multicolumn{4}{c}{ Parameters } \\
\cline { 2 - 5 } & $\mathbf{p H}$ & \multicolumn{3}{c}{ Carbon sources } \\
\cline { 2 - 5 } & 3.0 & 3.40 & 4.71 & 5.66 \\
\hline \multirow{2}{*}{ B. megaterium } & 5.0 & 3.03 & 1.24 & 5.24 \\
LBPMA- & 7.0 & 2.06 & 1.69 & 2.42 \\
APFSG3Isox & 9.0 & 4.18 & 2.01 & 3.79 \\
& 3.0 & 0.92 & 4.72 & 7.30 \\
B. toyonensis & 5.0 & 2.28 & 5.17 & 7.92 \\
LBPMA- & 7.0 & 3.33 & 2.86 & 6.96 \\
ACOPR1.Isox & 9.0 & 1.14 & 3.49 & 6.66 \\
& 3.0 & 1.91 & 2.49 & 1.52 \\
B. pumilus & 5.0 & 1.93 & 2.06 & 1.50 \\
LBPMA-BLD07 & 7.0 & 1.70 & 0.73 & 1.03 \\
& 9.0 & 1.60 & 2.36 & 1.26 \\
B. thuringiensis & 3.0 & 0.55 & 3.65 & 3.40 \\
LBPMA-EFIII & 5.0 & 1.39 & 3.11 & 3.73 \\
& 7.0 & 1.55 & 2.37 & 2.88 \\
& 9.0 & 1.29 & 0.62 & 2.93 \\
\hline
\end{tabular}

the filamentous fungus Aspergillus flavus studied by Aljuboori et al. (2013).

Comparing the flocculation activities of the tested microorganisms for the different nitrogen sources studied (Table 2), it was verified that these were individually less efficient after $24 \mathrm{~h}$ of cultivation of Bacillus spp. than the standard combined source [urea, yeast extract and $\left(\mathrm{NH}_{4}\right)_{2} \mathrm{SO}_{4}$ ].

Bacterial strains can use combined nitrogen sources to produce bioflocculants (Deng et al., 2005; Gong et al., 2008; Xia et al., 2008). For example, Gong et al. (2008) indicated that a mixture of urea and beef extract showed substantial improvement in the production of bioflocculants by Serratia. Xia et al. (2008) showed that the combination of peptone, yeast and beef extract as source of nitrogen was quite effective, but only peptone (organic nitrogen source) was the most profitable, with high bioflocculant production by Proteus mirabilis strain TJ-1. Also, Sekelwa et al. (2013) reported that a complex nitrogen source consisting of urea, yeast extract and $\left(\mathrm{NH}_{4}\right)_{2} \mathrm{SO}_{4}$ supported optimum bioflocculant production by Virgibacillus sp. On another hand, Deng et al. (2005) reported that peptone combined with sodium nitrate is the most suitable source of nitrogen for bioflocculant

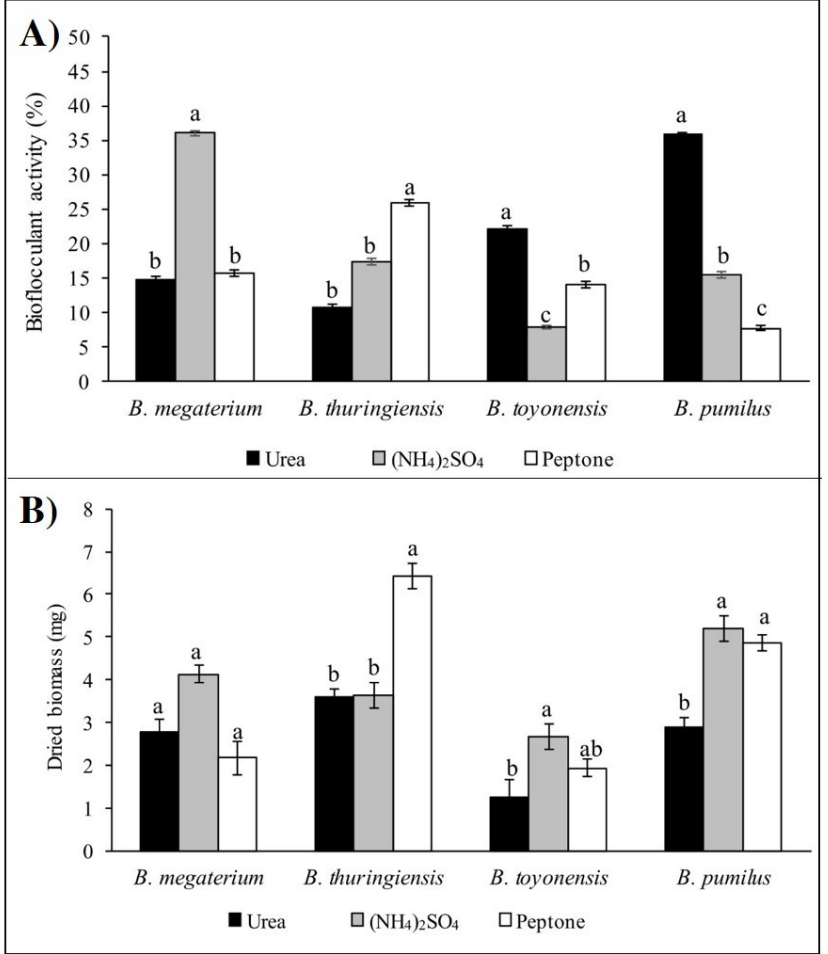

Figure 4. Effect of nitrogen sources on the bioflocculant production (A) and dried biomass (B), after $24 \mathrm{~h}$ of incubation (at $37^{\circ} \mathrm{C}$, dark, $160 \mathrm{rpm}$ of orbital shaking) of $B$. megaterium LBPMA-APFSG3Isox, $B$. toyonensis LBPMA-ACOPR1.Isox, B. pumilus LBPMA-BLD07and B. thuringiensis LBPMA-EFIII, on media with the best carbon sources and initial $\mathrm{pH}$ values for such production. Bars of the same color followed by different letters indicate subgroups with statistically significant differences, according to Tukey test $(\rho<0.05)$.

production by the fungus Aspergillus parasiticus, but when it was combined with $\left(\mathrm{NH}_{4}\right)_{2} \mathrm{SO}_{4}$, no bioflocculant was produced.

Therefore, according to the composition and initial $\mathrm{pH}$ of the culture media, different bacteria produce different chemical classes of the flocculants.

\section{Characterization of produced biosurfactant}

The infrared absorption spectrum (FTIR) of a compound is probably its most original physical property, so the spectrum is often called the fingerprint

Table 2. Bioflocculant activity (\%) of the cultures of B. megaterium LBPMA-APFSG3Isox, B. toyonensis LBPMAACOPR1.Isox, $B$. pumilus LBPMA-BLD07 and $B$. thuringiensis LBPMA-EFIII with different nitrogen sources during $24 \mathrm{~h}$ of incubation $\left(37^{\circ} \mathrm{C}\right.$, dark, $160 \mathrm{rpm}$ of orbital shaking).

\begin{tabular}{ccccc}
\hline \multirow{2}{*}{ Strains } & \multicolumn{3}{c}{ Nitrogen source } \\
\cline { 2 - 5 } & $\begin{array}{c}\text { Urea, yeast extract } \\
\text { and }\left(\mathbf{N H}_{4}\right)_{2} \mathbf{S O}_{\mathbf{4}}\end{array}$ & Peptone & Urea & $\left.\mathbf{( N H}_{\mathbf{4}}\right)_{2} \mathbf{S O}_{\mathbf{4}}$ \\
\hline B. megaterium LBPMA-APFSG3Isox & 34 & 16 & 15 & $\mathbf{3 6}$ \\
B. toyonensis LBPMA-ACOPR1.Isox & 21 & 8 & $\mathbf{2 2}$ & 14 \\
B. pumilus LBPMA-BLD07 & 39 & 8 & $\mathbf{3 6}$ & 15 \\
B. thuringiensis LBPMA-EFIII & 33 & $\mathbf{2 6}$ & 11 & 17 \\
\hline
\end{tabular}


of a molecule. Then, FTIR analysis of the bioflocculant produced by each studied Bacillus strain was performed to detect the presence of any functional groups that could contribute to its activity. In the achieved spectra (Figure 5), an intense broad-stretching peak was found at $3261 \mathrm{~cm}^{-1}$ for the bioflocculant of $B$. megaterium LBPMA-APFSG3Isox, $3269 \mathrm{~cm}^{-1}$ for that of $B$. toyonensis LBPMA-ACOPR1.Isox, $3263 \mathrm{~cm}^{-1}$ for that of $B$. pumilus LBPMA-BLD07 and $3259 \mathrm{~cm}^{-1}$ for that of $B$. thuringiensis LBPMA-EFIII, all characteristic of the hydroxyl groups $(-\mathrm{OH})$.

In addition, bands of $1309 \mathrm{~cm}^{-1}, 1377 \mathrm{~cm}^{-1}$ and 1402 $\mathrm{cm}^{-1}$, characteristic of symmetric stretch $(\mathrm{C}=\mathrm{O})$ of carboxylate (Deng et al., 2003), are representative of the carboxyl group, and they were found for the flocculants, respectively, of $B$. toyonensis LBPMA-ACOPR1. Isox, $B$. thuringiensis LBPMA-EFIII and $B$. pumilus LBPMA-BLD07. Ranges of a weak stretching $(\mathrm{C}-\mathrm{H})$ vibration were observed at $2960 \mathrm{~cm}^{-1}, 2916 \mathrm{~cm}^{-1}, 2960$ $\mathrm{cm}^{-1}$ and $2958 \mathrm{~cm}^{-1}$, respectively, in the spectra of the flocculants of $B$. megaterium LBPMA-APFSG3Isox, $B$. toyonensis LBPMA-ACOPR1.Isox, B. pumilus
LBPMA-BLD07 and B. thuringiensis LBPMA-EFIII. Bands at $1037 \mathrm{~cm}^{-1}, 1051 \mathrm{~cm}^{-1}, 1020 \mathrm{~cm}^{-1}$ and 1022 $\mathrm{cm}^{-1}$, were respectively found for the bioflocculants of $B$. megaterium LBPMA-APFSG3Isox, B. toyonensis LBPMA-ACOPR1.Isox, $B$. pumilus LBPMABLD07and $B$. thuringiensis LBPMA-EFIII, and indicate the presence of the methoxy group (Zheng et al., 2008). On another hand, a peak of absorption at $1261 \mathrm{~cm}^{-1}$ was found in the spectra of bioflocculants of $B$. megaterium LBPMA-APFSG3Isox, B. toyonensis LBPMA-ACOPR1.Isox and B. thuringiensis LBPMAEFIII, while for $B$. pumilus LBPMA-BLD07 this band appeared at $1228 \mathrm{~cm}^{-1}$, and both indicate the presence of $\mathrm{CO}$ stretch in an ether or alcohol (Abd-El-Haleem et al., 2008). Hydroxyl and carboxyl groups play a key role in the flocculation of suspended particles because they provide adsorption sites where the suspended particles can be attached (Okaiyeto et al., 2016). Absorption peaks around $1000-1100 \mathrm{~cm}^{-1}$ are known to be characteristic of all sugar derivatives (Zheng et al., 2008).

Polysaccharides contain a significant number of hydroxyl groups, which have a broad absorption band

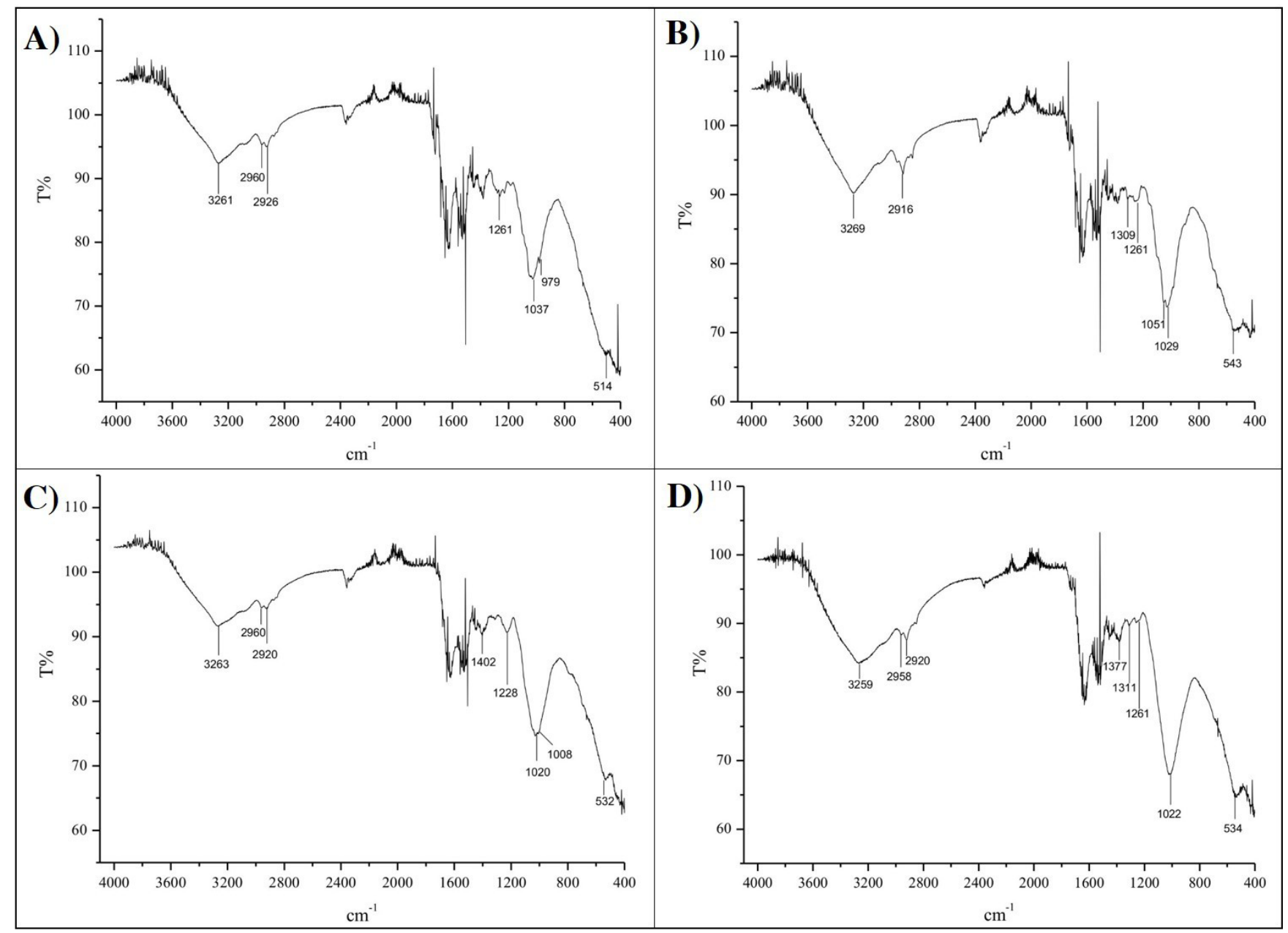

Figure 5. Fourier-transform infrared (FTIR) spectroscopy of bioflocculant produced by Bacillus megaterium LBPMA-APFSG3Isox (A), B. toyonensis LBPMA-ACOPR1.Isox (B), B. pumilus LBPMA-BLD07 (C) and $B$. thuringiensis LBPMA-EFIII (D) after $72 \mathrm{~h}$ of incubation (at $37^{\circ} \mathrm{C}$, dark, $160 \mathrm{rpm}$ of orbital shaking). 
above $3000 \mathrm{~cm}^{-1}$, as in the studied bioflocculants, suggesting they are polysaccharides. Deng et al. (2003) documented that B. mucilaginosus secreted a bioflocculant named MBFA9, which, from infrared analysis, revealed the presence of carboxyl and hydroxyl groups as the major functional groups in this molecule - a polysaccharide composed mainly of amino-sugars, uronic acids and neutral sugars. Feng and $\mathrm{Xu}$ (2008) observed that the acid flocculant produced by Bacillus sp. BF3-3 is composed by polysaccharide and protein, while Gao et al. (2006) found that the flocculant produced by Vagococcus sp. W31 is a heteropolysaccharide formed mainly by neutral glycol and uronic acid. Gomaa (2012), studying the bioflocculant produced by Pseudomonas aeruginosa, observed the presence of carboxyl, hydroxyl, amino and sugar groups, characteristics of exopolymers. Dongchen et al. (2013) and Kavita et al. (2013), investigating the FTIR spectra of flocculants produced by isolates of the fungus Phanerochaete chrysosporium and the bacteria Vibrio campbellii, observed groups characteristic of polysaccharides.

Therefore, the FTIR spectra of the bioflocculants produced by the studied strains showed the presence of carboxyl, hydroxyl and methoxy groups (Figures 7 and 8), which are characteristic of polysaccharides and preferred for flocculation (Ntsangani et al., 2017).

\section{CONCLUSION}

In the present study, we investigated the flocculating efficiency and chemical properties of the bioflocculants produced by four strains of Bacillus (B. megaterium LBPMA-APFSG3Isox, $B$. toyonensis LBPMAACOPR1.Isox, B. pumilus LBPMA-BLD07 and $B$. thuringiensis LBPMA-EFIII). Maximum flocculating activity measurements were established and the results showed the maximum value of $57 \%$ for B. pumilus LBPMA-BLD07 after 72h. The presence of hydroxyl, carboxyl and methoxy groups in the bioflocculant of all strains indicate they are polysaccharides.

\section{ACKNOWLEDGEMENTS}

The authors gratefully acknowledge financial support by "Conselho Nacional de Desenvolvimento Científico" (CNPq) and "S.A. Usina Coruripe Açúcar e Álcool".

\section{REFERENCES}

Abd-El-Haleem, D., Al-Thani, R., Al-Mokemy, T., AlMarii, S., Hassan, F. Isolation and characterization of extracellular bioflocculants produced by bacteria isolated from Quatari ecosystems. Polish Journal of Microbiology, 57, 231-239 (2008).
Aljuboori, A., Idris, A., Abdullah N., Mohamad R. Production and characterization of a bioflocculant produced by Aspergillus flavus. Bioresource Technology, 127,489-493 (2013). https://doi. org/10.1016/j.biortech.2012.09.016

Barros, F., Simiqueli, A., Andrade, C. de, Pastore. G. Production of enzymes fromagroindustrial wastes by biosurfactant-producing strains of Bacillus subtilis. Biotechnology Research International, 2013, 1-9 (2013). https://doi.org/10.1155/2013/103960

Choi, C., Yoo, S., Oh, I., Park, S. Characterization of an extracellular flocculating substance produced by a planktonic cyanobacterium, Anabaena sp. Biotechnology Letters, 20, 643-646 (1998). https:// doi.org/10.1023/A:1005358204636

CONAMA 430 - Conselho Nacional de Meio Ambiente, Legislação Ambiental Federal, Resolução $n^{\circ}$ 430, 2011. Available at: www.mma.gov.br/conama.

Deng, S., Bai, R., Hu, X., Luo, Q. Characteristics of a bioflocculant produced by Bacillus mucilaginosus and its use in starch wastewater treatment. Applied Microbiological Biotechnology, 60, 588-593 (2003). https://doi.org/10.1007/s00253-002-11595

Deng, S., Yu, G., Ting, Y. Production of a bioflocculant by Aspergillus parasiticus and its application in dye removal. Colloids and Surfaces B: Biointerfaces, 44, 179-186 (2005). https://doi.org/10.1016/j. colsurfb.2005.06.011

Dongchen, Z., Zhixiang, H., Zhiyong, L., Tao, W. Experimental research on Phanerochaete chrysosporium as coal microbial flocculant. International Journal of Mining Science and Technology, 23, 521-524, (2013). https://doi. org/10.1016/j.ijmst.2013.07.009

Feng, D., Xu, S. Characterization of bioflocculant MBF3-3 produced by an isolated Bacillus sp. World Journal of Microbiology and Biotechnology, 24, 1627-1632 (2008). https://doi.org/10.1007/ s11274-008-9654-1

Gong, W., Wang, S., Sun, X., Liu, X., Yue, Q., Gao, B. Bioflocculant production by culture of Serratia ficaria and its application in wastewater treatment. Bioresource Technology, 99, 4668-4674 (2008). https://doi.org/10.1016/j.biortech.2007.09.077

Gomaa, E. Production and Characteristics of a Heavy Metals Removing Biofocculant Produced by Pseudomonas aeruginosa. Polish Journal of Microbiology, 61, 281-289 (2012).

Guo, H., Hong, C., Zhang, C., Zheng, B., Jiang, D., Qin, W. Bioflocculants' production from a cellulasefree xylanase-producing Pseudomonas boreopolis G22 by degrading biomass and its application in cost-effective harvest of microalgae. Bioresource Technology, 255, 171-179 (2018). https://doi. org/10.1016/j.biortech.2018.01.082 
He, J., Zou, J., Shao, Z., Zhang, J., Liu, Z., Yu, Z. Characteristics and flocculating mechanism of a novel bioflocculant HBF-3 produced by deep-sea bacterium mutant Halomonas sp. V3a'. World Journal of Microbiology and Biotechnology, 26, 1135-1141, 2010. https://doi.org/10.1007/s11274009-0281-2

Kavita, K., Mishra, A., Jha, B. Extracellular polymeric substances from two biofilm forming Vibrio species: Characterization and applications. Carbohydrate Polymers, 94, 882-888 (2013). https://doi. org/10.1016/j.carbpol.2013.02.010

Kurane, R., Hatamochi, K., Kakuno, T., Kiyohara, M., Hirano, M., Taniguchi, Y. Production of a bioflocculant by Rhodococcus erythropolis S-1 grown on alcohols. Bioscience, Biotechnoloy and Biochemistry, 58, 428-429 (1994). https://doi. org/10.1271/bbb.58.428

Li, Z., Zhong, S., Lei, H., Chen, R., Yu, Q., Li, H. Production of a novel bioflocculant by Bacillus licheniformis X14 and its application to low temperature drinking water treatment. Bioresource Technology, 100, 3650-3656 (2009). https://doi. org/10.1016/j.biortech.2009.02.029

Li, Q., Liu, H.L., Qi, Q., Wang, F., Zhang, Y. Isolation and characterization of temperature and alkaline stable bioflocculant from Agrobacterium. sp. M503. New Biotechnology, 2010, 789-794 (2010). https://doi.org/10.1016/j.nbt.2010.09.002

Li, O., Lu, C., Liu, A., Zhu, L., Wang, P., Qian, C., Jiang, X., Wu, X. Optimization and characterization of polysaccharide-based bioflocculant produced by Paenibacillus elgii B69 and its application in wastewater treatment. Bioresource Technology, 134, 87-93 (2013). https://doi.org/10.1016/j. biortech.2013.02.013

Liu, W., Wang, K., Li, B., Yuan, H., Yang, J. Production and characterization of an intracellular bioflocculant by Chryseobacterium daeguense W6 cultured in low nutrition medium. Bioresource Technology, 101, 1044-1048 (2010). https://doi. org/10.1016/j.biortech.2009.08.108

Liu, W., Liu, C., Sun, D. Complete Genome Sequence of a Novel Bioflocculant-Producing Strain, Microbacterium paludicola CC3. Genome Announcements, 5, 1-2 (2017). https://doi. org/10.1128/genomeA.01008-17

Luo, L., Zhao, Z., Huang, X., Du, X., Wang, C., Li, J., Wang, L. Xu, Q. Isolation, Identification, and Optimization of Culture Conditions of a Bioflocculant-Producing Bacterium Bacillus megaterium SP1 and Its Application in Aquaculture Wastewater Treatment. Biomed Research International, 2016, 1-9 (2016). https://doi. org $/ 10.1155 / 2016 / 2758168$
Makapela, B., Okaiyeto, K., Ntozonke, N., Nwodo, U., Green, E., Mabinya, L., Okoh, A. Assessment of Bacillus pumilus isolated from Fresh Water Milieu for bioflocculant production. Applied Sciences, 6, 211-231 (2016). https://doi. org/10.3390/app6080211

Martins, R., Hatti-Kaul, R. A new cyclodextrin glycosyltrnasferase from an alkaliphilic Bacillus agaradhaerens isolate: purification and characterisation. Enzyme and Microbial Technology, 30, 116-124 (2002). https://doi. org/10.1016/S0141-0229(01)00461-6

Moussas, P., Zouboulis, A. A new inorganic-organic composite coagulant, consisting of polyferric sulfate (PFS) and polyacrylamide (PAA). Water Research, 43, 3511-3524 (2009). https://doi. org/10.1016/j.watres.2009.05.015

Nakata K., Kurane, R. Production of an extracellular polysaccharide bioflocculant by Klebsiella pneumoniae. Bioscience, Biotechnology and Biochemistry, 63, 2064-2068 (1999). https://doi. org/10.1271/bbb.63.2064

Ntsangani, N., Okaiyeto, K., Uchechukwu, N.U., Olaniran, A.O., Mabinya, L.V., Okoh, A.I. Bioflocculation potentials of a uronic acidcontaining glycoprotein produced by Bacillus sp. AEMREG4 isolated from Tyhume River, South Africa. 3 Biotech, 7, 1-12 (2017). https://doi. org/10.1007/s13205-017-0695-8

Nwodo, U., Okoh, A. Characterization and flocculation properties of biopolymeric flocculant (glycosaminoglycan) produced by Cellulomonas sp. Okoh. Journal of Applied Microbiology, 114, 1325-1337 (2013). https://doi.org/10.1111/ jam. 12095

Okaiyeto, K., Nwodo, U., Mabinya, L., Okoli, A., Okoh, A. Characterization of a bioflocculant (MBF-UFH) produced by Bacillus sp. AEMREG7. International Journal of Molecular Sciences, 16, 12986-13003 (2015). https://doi.org/10.3390/ ijms 160612986

Okaiyeto, K., Nwodo, U., Mabinya, L., Okoli, A., Okoh, A. Evaluation of flocculating performance of a thermostable bioflocculant produced by marine Bacillus sp. Environonmental Technology, 37, 1829-1842 (2016). https://doi.org/10.1080/095 93330.2015.1133717

Pathak, M., Sarma, H.K., Bhattacharyya, K.G., Subudhi, S., Bisht, V., Lal, B., Devi, A. Characterization of a Novel Polymeric Bioflocculant Produced from Bacterial Utilization of n-Hexadecane and Its Application in Removal of Heavy Metals. Frontiers in Microbiology, 8, 1-15 (2018). https:// doi.org/10.3389/fmicb.2017.00170 
Prasertsan, P., Dermlim, W., Doelle, H., Kennedy, J. Screening, characterization and flocculating property of carbohydrate polymer from newly isolated Enterobacter cloacae WD7. Carbohydrate Polymers, 66, 289-297 (2006). https://doi. org/10.1016/j.carbpol.2006.03.011

Pylro, V., Roesch, L., Ortega, J., Amaral, A. do, Tótola, M., Hirsch, P., Rosado, A., Góes-Neto, A., Costa, A. da, Rosa, C., Morais, D., Andreote, F., Duarte, G., Melo, I. de, Seldin, L., Lambais, M., Hungria, M., Peixoto, R., Kruger, R., Tsai, S., Azevedo, V. Brazilian Microbiome Project: Revealing the Unexplored Microbial Diversity Challenges and Prospects. Microbial Ecology, 67, 237-241 (2014). https://doi.org/10.1007/s00248013-0302-4

Salehizadeh, H., Shojaosadati, S. Extracellular biopolymeric flocculants: Recent trends and biotechnology importance. Biotechnology Advances, 19, 371-385 (2001). https://doi. org/10.1016/S0734-9750(01)00071-4

Salehizadeh, H., Yan, N. Recent advances in extracellular biopolymer flocculants. Biotechnology Advances, 32, 1506-1522 (2014). https://doi.org/10.1016/j.biotechadv.2014.10.004

Sekelwa, C., Anthony, U., Vuyani, M., Anthony, O. Characterization of a thermostable polysaccharide bioflocculant produced by Virgibacillus species isolated from Algoa bay. African Journal of Microbiology Resource, 7, 2925-2938 (2013). https://doi.org/10.5897/AJMR12.2371

Sheng, Y., Zhang, Q., Sheng, Y., Li, C., Wang, $\mathrm{H}$. Screening and flocculating properties of bioflocculant-producing microorganisms. Journal of University of Science and Technology Beijing, Mineral, Metallurgy, Material, 13, 289-292 (2006). https://doi.org/10.1016/S1005-8850(06)60061-3

Wan, C., Zhao, X.Q., Guo, S.L., Asraful Alam, M., Bai, F.W. Bioflocculant production from Solibacillus silvestris W01 and its application in cost-effective harvest of marine microalga Nannochloropsis oceanica by flocculation. Bioresource Technology, 135, 207-212 (2013). https://doi.org/10.1016/j. biortech.2012.10.004
Wang, L., Ma, F., Qu, Y., Sun, D., Li, A., Guo, J., Yu, B. Characterization of a compound bioflocculant produced by mixed culture of Rhizobium radiobacter F2 and Bacillus sphaericus F6. World Journal of Microbiology and Biotechnology, 27, 2559-2565 (2011). https://doi.org/10.1007/s11274-011-0726-2

Wong, Y., Ong, S., Teng, T., Aminah, N., Kumaran, K. Production of bioflocculant by Staphylococcus cohnii ssp. from palm oil mill effluent (POME). Water, Air \& Soil Pollution, 223, 3775-3781 (2012). https://doi.org/10.1007/s11270-012-1147-z

Xia, S., Zhang, Z., Wang, X., Yang, A., Cheng, L., Zhao, J., Leonard, D., Jaffrezic-Renault, N. Production and characterization of bioflocculant by Proteus mirabilis TJ-1. Bioresource Technology, 99, 6520-6527 (2008). https://doi.org/10.1016/j. biortech.2007.11.031

Xiong, Y., Wang, Y., Yu, Y., Li, Q., Wang, H., Cheng, R., $\mathrm{He}$, N. Production and Characterization of a Novel Bioflocculant from Bacillus licheniformis. Applied and Environmental Microbiology, 76, 2778-2782 (2010). https://doi.org/10.1128/AEM.02558-09

Yang, Q., Luo, K., Liao, D., Li, X., Wang, D., Liu, X., Zeng, G., Li, X. A novel bioflocculant produced by Klebsiella sp. and its application to sludge de watering. Water and Environmental Journal, 26, 560-566 (2012). https://doi.org/10.1111/j.17476593.2012.00319.x

Yim, J., Kim, S., Ahn, S., Lee, H. Characterization of a novel bioflocculant, p-KG03, from a marine dinoflagellate, Gyrodinium impudicum KG03. Bioresource Technology, 98, 361-367 (2007). https://doi.org/10.1016/j.biortech.2005.12.021

Zhang, Z., Lin, B., Xia, S., Wang, X., Yang, A. Production and application of a novel bioflocculant by multiple-microorganism consortia using brewery wastewater as carbon source. Journal of Environmental Sciences, 19, 667-673 (2007). https://doi.org/10.1016/S1001-0742(07)60112-0

Zheng, Y., Ye, Z., Fang, X., Li, Y., Cai, W. Production and characteristics of a bioflocculant produced by Bacillus sp. F19. Biosource Technology, 99, 7686-7691 (2008). https://doi.org/10.1016/j. biortech.2008.01.068 
